\title{
KESALAHAN EJAAN DALAM MENULIS BERITA SISWA KELAS IX SMP LABORATORIUM PERCONTOHAN UPI TAUN AJARAN 2013/2014
}

\author{
Ida Jubaidah \\ MGMP Bahasa Sunda Kota Bandung \\ Pos-el: idajubed78@gmail.com
}

\begin{abstract}
ABSTRAK
Latar belakang penelitian ini karena siswa beranggapan bahwa pembelajaran bahasa Sunda sangat sulit. Hal itu menyebabkan siswa tidak begitu hirau terhadap pembelajaran tersebut, termasuk dalam pembelajaran menulis, misalnya kurang memperhatikan ejaan. Penelitian ini bertujuan untuk mengetahui dan mendeskripsikan kesalahan ejaan yang dilakukan oleh siswa kelas IX SMP Laboratorium Percontohan UPI tahun ajaran 2013/2014. Uraiannya menyaran kepada kesalahan (1) penggunaan aksara, (2) menulskan aksara, (3) menuliskan kecap, (4) menuliskan unsur serapan, dan (5) penggunaan tanda baca. Penelitian ini menggunakan metode deskriptif dengan tehnik tes. Pengolahan data dilakukan dengan analisis dokumen. Sumber data dalam penelitian ini yaitu siswa kelas IX SMP Laboratorium Percontohan UPI tahun ajaran 2013/2014. Data yang digunakan merupakan kesalahan ejaan dalam menulis berita yang dilakukan oleh siswa sekolah terebut. Hasilnya dapat disimpulkan bahwa siswa masih banyak melakukan kesalahan ejahan dalam menulis berita. Kesalahannya meliputi : (1) kesalahan penggunaan aksara 101 (43,72\%); (2) kesalahan menuliskan aksara 83 (38,10\%); (3) kesalahan menuliskan kata 26 (11,25\%); (4) kesalahan menuliskan unsur serapan 7 (3,03\%); dan (5) kesalahan penggunaan tanda baca $14(6,06 \%)$. Berdasarkan hasil tersebut, guru harus lebih intensif dalam mengajarkan bahasa Sunda, terutama dalam membedakan vokal é, e, dan eu.
\end{abstract}

Kata kunci: kesalahan éjahan, menulis berita.

\section{SPELLING ERROR IN NEWS WRITING OF STUDENTS OF GRADE IX OF SMP LABORATORIUM PERCONTOHAN UPI SCHOOL YEAR 2013/2014}

\begin{abstract}
This study is come from the idea that students consider that learning Sundanese is difficult, which makes them tend to be ignorant in Sundanese courses, including in writing, such as not paying attention to how to spell it. This study is aimed to find out and describe spelling errors done by students of grade IX of SMP Laboratorium Percontohan UPI School Year 2013/2014. The spelling error includes (1) letters usage; (2) letters writing; (3) words writing; (4) uptake elements writing; and (5) punctuation usage. This study is using descriptive method with test technique. The data is processed using document analysis. Data source in this study are students of grade IX SMP Laboratorium Percontohan UPI School Year 2013/2014. Data in this study are spelling errors in writing news done by the students. The result of this study shows that most of students still doing spelling errors in writing news. The errors includes (2) error in using letters with total of 101 items $(43,72 \%)$; (2) error in writing letters with total of 83 items $(38,10 \%)$; (3) error in writing words with total of 26 items (11,25\%); (4) error in writing uptake elements with total of 7 items (3,03\%); and (5) error in using punctuations with total of 14 items (6,06\%). Based
\end{abstract}


on the results above, it can be concluded that teachers have to be more intensively teaching Sundanese spelling to students, especially in distinguishing vocal é, eandeu.

Keywords: spelling error, news writing

\section{PENDAHULUAN}

Manusia sebagai makhluk sosial, tentunya memerlukan orang lain dalam kehidupannya. Oleh karena itu, bahasa memiliki peranan yang penting dalam komunikasi antara manusia yang satu dengan yang lainnya. Ada dua jenis komunikasi yang dilakukan manuisa malalui bahasa, yaitu bahasa lisan melalui lisan dan bahasa tulisan melalui tulisan.

Dalam pembelajaran bahasa dikenal empat aspek keterampilan berbahasa, yaitu menyimak, berbicara, membaca, dan menulis. Menulis bersifat produktif, artinya kegiatan yang menghasilkan sebuah karya. Menurut Tarigan (2008, hlm.22), menulis yaitu menurunkan atau melukiskan lambang-lambang grafik yang menggambarkan suatu bahasa yang dipahami oleh seseorang, sehingga orangorang lain dapat membaca lambanglambang grafik tersebut kalau mereka memahami bahasa dan gambaran grafik tadi. Jadi, menulis merupakan salah satu keterampilan berbahasa yang bersifat produktif yang memiliki tujuan untuk menyampaikan ide, rasa, keinginan melalui media tulis kepada orang lain.

Dalam pembelajaran menulis, siswa dituntut untuk menuliskan ide, rasa, keinginannya melalui tulisan. Salah satunya dapat melalui berita. Pembelajaran berita ada di kelas IX. Berita yaitu laporan tercepat yang berisi fakta, sifatnya masih baru dan penting untuk diketahui oleh masyarakat.

Fungsi berita itu sendiri yaitu untuk memberitahukan masyarakat mengenai kejadian yang sedang atau telah berlangsung, menambah pengetahuan, dan memberikan informasi-informasi yang dibutuhkan oleh masyarakat.

Menurut Iskandarwassid \& Sunendar (2008, hlm.291), keterampilan menulis merupakan keterampilan paling sulit dibandingkan tiga keterampilan lainnya. Hal itu sesuai dengan keadaan di lapangan. Siswa menganggap bahwa bahasa Sunda itu sulit. Oleh karena itu, siswa tidak sungguh-sungguh dalam pengajaran bahasa Sunda. Begitu juga dalam menulis berita, karena banyak hal yang harus diperhatikan dalam menulis, salahsatunya adalah ejaan.

Ejaan yaitu aturan menuliskan lambang-lambang suara bahasa menggunakan aksara (Sudaryat dalam Fauziah, 2005, hlm.25). Ejaan biasanya mencakup aturan menggunakan huruf, menuliskan kata, menuliskan unsur serapan, dan penggunaan tanda baca (Prawirasumantri, 2007, hlm.30). Dalam Palanggeran Éjahan Basa Sundayang disusun oleh Jurusan Pendidikan Bahasa Daerah, ejaan mencakup aturan menggunakan huruf, menuliskan huruf, menuliskan kata, menuliskan unsur serapan, dan penggunaan tanda baca.

Ejaan penting dalam menulis, begitu juga dalam menulis berita. Padahal ejaan begitu penting dalam menulis. Karena, jika salah menggunakan ejaan, bisa menimbulkan multitafsir. Contoh kesalahan dalam menuliskan huruf, seperti menuliskan kata /bébék/ dan /bebek/. Dua kata tersebut memiliki arti yang berbeda. dalam menuliskan kata bébék, jika vokal énya, tidak menggunakan panéléng, akan menjadi bebek. tentunya hal ini akan menimbulkan arti yang berbeda, antara maksud penulis dan pembaca.

Hal tersebut merupakan hal yang menarik peneliti untuk meneliti kesalahan ejaan yang dilakukan siswa dalam menulis berita. 


\section{METODE}

Metode yang digunakan dalam penelitian ini adalah metode deskriptif. Penelitian ini merupakan penelitian yang ditujukan untuk mengumpulkan informasi mengenai satu gejala yang ada, yaitu keadaan gejala seadanya sewaktu penelitian (Arikunto, 2009, hlm.234). Penelitian ini memiliki tujuan untuk mengetahui dan mendeskripsikan kesalahan ejaan yang dilakukan oleh siswa kelas IX SMP Laboratorium Perocontohan UPI Tahun Ajaran 2013/2014 dalam bentuk berita.

Data dari penelitian ini adalah kesalahan ejaan dalam warta siswa kelas IX SMP Laboratorium Percontohan UPI Tahun Ajaran 2013/2014. Sedangkan yang menjadi sumber data adalah siswa kelas IX SMP Laboratorium Percontohan UPI Tahun Ajaran 2013/2014 yang berjumlah 23 berita. Dari sumber data tersebut, dicatat kesalahan ejaannya yang mencakup kesalahan menggunakan huruf, kesalahan menuliskan huruf, kesalahan menuliskan kata, kesalahan menuliskan unsur serapan, dan kesalahan penggunaan tanda baca.

Desain penelitiannya, yaitu (1) menentukan masalah, (2) menentukan sumber data, (3) mengumpulkan data, (4) mengolah data, (5) mendeskripsikan hasil analisis, dan (6) menyimpulkan hasil analisis. Teknik yang dipakai untuk mengumpulkan data adalah teknik tes, sedangkan dalam mengolah data digunakan teknik analisis dokumen.

\section{HASIL DAN PEMBAHASAN}

Berdasarkan data yang diperoleh, jumlah kesalahan ejaan dari berita yang ditulis oleh siswa adalah 231 kesalahan. Kesalahan tersebut dibagi menurut tipe kesalahannya, yaitu: (1) kesalahan menggunakan huruf ada 101 kesalahan; (2) kesalahan menuliskan huruf 83 kesalahan; (3) kesalahan menuliskan kata ada 26 kesalahan; (4) kesalahan menuliskan unsur serapan ada 7 kesalahan; dan (5) kesalahan menggunakan tanda baca ada 14 kesalahan.

Kesalahan menggunakan huruf adalah kesalahan menggunakan abjad (konsonan, vokal, dan suku kata). Kesalahan yang ditemukan adalah kesalahan dalam menggunakan vokal é,e, dan $e u$. Berdasarkan hasil analisis, ditemukan 101 kesalahan menggunakan huruf. Dalam menggunakan vokal, siswa masih tertukar antara menggunakan vokal é, eu, dan eu. Tertukarnya vokal édan $e$, berjumlah 88 kata; tertukarnya vokal $\mathrm{eu}$ dan $e$ berjumlah 10 kata; tertukarnya vokal $e$ dan $e u$ berjumlah 2 kata; dan tertukarnya vokal $e$ dan $e u$ berjumlah 1 kata. Kata yang paling sering dituliskan salah, yaitu kata téh dengan frekuensi 16 kali.

Kesalahan menuliskan huruf terdiri dari kesalahan menuliskan huruf kapital dan kesalahan menuliskan huruf miring.

1) Kesalahan menuliskan huruf kapital adalah kesalahan menuliskan huruf kapital yang tidak sesuai dengan aturan. Berdasarkan data yang telah dianalisis, kesalahan menuliskan huruf kapital yang dilakukan, adalah kesalahan (1) menuliskan huruf kapital di tengah kalimatyang berjumlah 6 kesalahan; (2) tidak menggunakan huruf kapital sesudah tanda titik yang berjumlah 9; (3) menuliskan kata singkatan yang berjumlah 3 ; (4) menuliskan judul yang berjumlah 7; (5) menuliskan nama daerah yang berjumlah 6; dan (6) menuliskan nama bulan yang berjumlah 1 kesalahan. Kesalahan terbanyak yang dilakukukan oleh siswa yaitu kesalahan tidak menggunakan huruf kapital setelah tanda titik, yang jumlahnya 9 kesalahan. Kesalahan tersebut bisa dilihat pada data (006), (017), (030), (035), (078), (142), (149), (150), dan (231).

2) Kesalahan menuliskan huruf miring adalah kesalahan dalam (1) menuliskan nama buku, majalah, dan surat kabar; (2) menegaskan atau menghususkan huruf; (3) menuliskan nama-nama ilmiah yang belum diserap seutuhnya. Kesalahan ini berjumlah 50. Kesemuanya itu adalah 
kesalahan dalam menuliskan unsur bahasa asing. Kata yang paling sering ditemukan adalah "Lonely", yang merupakan judul lagu dalam bahasa Inggris. Dalam menuliskan kata tersebut, siswa tidak memiringkannya atau tidak digarisbawahi. Kata tersebut dapat dilihat pada data (015), (025), (042), dan (134).

Dalam menuliskan kata, ditemukan ada 26 kesalahan. Kesalahannya terdiri dari kesalahan (1) menuliskan angka dan lambang bilangan; (2) menuliskan kata sambung,(3) menuliskan imbuhan,dan (4) menuliskan kata ganti.

1) Dalam menuliskan angka dan lambang bilangan ditemukan tujuhkesalahan, yaitu kesalahan dalam menuliskan angka yang kurang dari 10 dan dalam menuliskan titimangsa. Dalam aturan ejaan, angka yang kurang dari 10, ditulis menggunakan huruf. Dalam kesalahan ini ditemukan lima kesalahan, yaitu pada data (005), (008), (013), (118), dan (191). Sedangkan dua kesalahan dalam menuliskan titimangsa, dapat dilihat pada data (115) dan data (133). Dalam menuliskan titimangsa, masih ada siswa yang menuliskannya menggunakan tanda geret (-) untuk memisahkan tanggal dan nama bulan, nama bulan dan tahun, seperti 13Januari-2014 (R02/IXC/3/5).

2) Kesalahan menuliskan kata sambung adalah kesalahan dalam menuliskan kata sambung yang seharusnya ditulis dipisah dengan kata sesudahnya, tapi siswa menuliskannya disatukan dengan kata sesudahnya. Setelah dianalisis, ditemukan kata sambung yang ditulis menyatu dengan kata sesudahnya, yaitu kata $d i, k a, k u$, dan di+-eun. Padahal dina aturan ejaan, menuliskan kata sambung dipisah dengan kata sesudahnya. Kata sambung yang banyak ditemukan dengan cara penulisan salah adalah di dengan frekuensi tujuh.
3) Kesalahan menuliskan kata berimbuhan adalah kesalahan menuliskan imbuhan yang seharusnya ditulis disatukan, tapi siswa menulisnya dipisah dengan kecap asalnya. Kesalahan dalam menuliskan kata berimbuhan berjumlahlima kesalahan.

4) Kesalahan dalam menuliskan kata ganti yang ditemukan dalam penelitian ini adalah kesalahan dalam menuliskan kata ganti orang ketiga, yaitu pada data (230). Kata terebut adalah barang-barangna. Padahal dalam aturan, kata ganti ditulis disatukan dengan kata sebelumnya.

Dalam menuliskan unsur serapan, ditemukan tujuh kesalahan. Semua kesalahan yang berupa kata tersebut, merupakan tulisan dan kaidah pengucapannya sudah disesuaikan dengan kaidah bahasa Sunda. Jadi, kata-kata tersebut bisa dicari artinya dalam kamus bahasa Sunda. Kata tersebut adalah goal, film, manfaat, sholatan, dan band. Seharusnya kata tersebut ditulis gul, pilem, mangpaat, solatan, dan bén.

Kesalahan menggunakan tanda baca dalam berita yang ditulis siswa ditemukan 14 kesalahan. Kesalahan tersebut terdiri dari kesalahan (1) tanda titik, (2) tanda kutip, (3) tanda strip, dan (4) tanda pisah.

1) Kesalahan menggunakan tanda titik (.) berjumlah tujuh. Semua kesalahannya berupa kesalahan tidak menggunakan tanda titik di akhir kalimat. Padahal menurut aturan, tanda titik digunakan di akhir kalimat.

2) Kesalahan menggunakan tanda kutip (“...”), berjumlah empat kesalahan. Kesalahannya yaitu dalam menuliskan judul film dan nama julukan. Padahal menurut aturan, dalam menuliskan judul film dan nama julukan diapit oleh tanda kutip.

3) Kesalahan menggunakan tanda strip (-), ditemukan dua kesalahan. Kesalahannya yaitu dalam 
menuliskan unsur Sunda dan unsur basa asing, Kesalahan ini ada pada data (049) dan data (140).

4) Kesalahan menggunakan tanda pisah $(-)$, berjumlah satu kesalahan. Kesalahan tersebut ada pada data (217), "Tina tanggal 16 nepi $k a$ tanggal 18 oktober 2013 ...”. Menurut aturan, tanda pisah digunakan di antara dua bilangan atau tanggal yang mengandung arti 'nepi ka'. Dari data di atas, "nepi ka tanggal'bisa diganti ngagunakeun tanda pisah (-)

Berdasarkan hasil penelitian di atas, kesalahan ejaan yang dilakukan oleh siswa bisa ditabelkan dalam tabel di bawah ini.

Tabél 1

Jumlah Kesalahan Ejaan

\begin{tabular}{clccc}
\hline No. & \multicolumn{1}{c}{ Tipe Kasalahan Ejaan } & Jumlah & $\mathbf{\%}$ \\
\hline 1. & Kesalahan menggunakan huruf & 101 & 43,72 \\
\hline 2. & Kesalahan menuliskan huruf & 83 & 35,93 \\
\hline 3. & Kesalahan menuliskan kata & 26 & 11,26 \\
\hline 4. & Kesalahan menuliskan unsur serapan & 7 & 3,03 \\
\hline 5. & Kesalahan menggunakan tanda baca & 14 & 6,06 \\
\hline & Jumlah & 231 & 100 \\
\hline
\end{tabular}

Berdasarkan data di atas, ternyata masih banyak terdapat kesalahan ejaan yang dilakukan siswa kelas IX SMP Laboratorium Percontohan UPI Taun Ajaran 2013/2014 dalam menulis berita. Hal ini sesuai dengan pendapat Iskandarwassid \& Sunendar (2008, hlm.291), bahwa keterampilan menulis merupakan keterampilan paling sulit dibandingkan tiga keterampilan lainnya.

\section{SIMPULAN}

Berdasarkan data yang telah dianalisis, kesalahan ejaan yang dilakukan oleh siswa dapat disimpulkan seperti di bawah ini.

a. Kesalahan dalam menggunakan huruf, yaitu kesalahan menggunakan vokal é, $e$, dan $e u$, berjumlah $101 \quad(43,72 \%)$. Tertukarnya vokal e, dan é berjumlah 88 (87,13\%); tertukarnya vokal e dan eu, berjumlah 10 kesalahan (9,90\%); tertukarnya vokal eu dan e, berjumlah 2 kesalahan (1,98\%); dan tertukarnya vokal é dan e berjumlah 1 kesalahan $(0,99 \%)$.

b. Kesalahan menuliskan huruf berjumlah 83 kesalahan $(35,93 \%)$. Kesalahan ini terdiri dari kesalahan menuliskan huruf kapital yang berjumlah $33(39,76 \%)$, dan kesalahan menuliskan huruf miring yang berjumlah $50(60,24 \%)$.

c. Kesalahan menuliskan kata berjumlah 26 kesalahan $(11,26 \%)$. Kesalahan ini terdiri dari kesalahan, (1) menuliskan angka dan lambang bilangan yang berjumlah 7 kesalahan (26,92\%); (2) kata sambung yang berjumlah 13 kesalahan (50\%); (3) menuliskan kata berimbuhan yang berjumlah 5 kesalahan $(19,23 \%)$; dan (4) menuliskan kata ganti yang berjumlah 1 kesalahan $(3,85 \%)$.

d. Kesalahan menuliskan unsur serapan berjumlah 7 kesalahan (3,03\%).

e. Kesalahan menggunakan tanda baca berjumlah 14 kesalahan $(6,06 \%)$. Kesalahan ini terdiri dari kesalahan menggunakan, (1) tanda titik yang berjumlah 7 kesalahan (50\%); (2) tanda kutip yang berjumlah 4 kesalahan $(14,29 \%)$; (3) tanda stripyang berjumlah 2 kesalahan (14,29\%); dan (4) tanda pisah yang berjumlah 1 kesalahan $(7,14 \%)$.

\section{PUSTAKA RUJUKAN}

Arikunto, S. (2009). Manajemen Penelitian. Jakarta: PT Rineka Cipta.

Fauziah, S. (2013). Analisis Kasalahan Éjahan dina Karangan Déskripsi 
Siswa Kelas XII MAN Jonggol Taun Ajaran 2012/2013. (Skripsi) Jurusan Pendidikan Bahasa Daerah-FPBSUPI Bandung: Tidak diterbitkan.

Iskandarwassid dan Sunendar, D. (2008). Strategi Pembelajaran Bahasa. Bandung: Refika Aditama.

Jurusan Pendidikan Bahasa Daerah FPBS UPI. (2008). Palanggeran Éjahan Basa Sunda (Édisi Révisi). Bandung: Sonagar Press.
Prawirasumantri, A. spk. (2007). Kamekaran, Adegan, jeung Kandaga Kecap Basa Sunda. Bandung: Geger Sunten.

Tarigan, H.G. (2008) Menulis Sebagai Suatu Keterampilan Berbahasa. Bandung: Angkasa.

\section{UCAPAN TERIMA KASIH}

Terima kasih kepada pengelola jurnal Lokabasa yang telah menerbitkan tulisan ini. Semoga tulisan ini ada manfaatnya bagi perkembangan ilmu pengetahuan. 